\title{
Archives of Epidemiology
}

\section{Assessing Knowledge of Sickle Cell Trait/Disease Inheritance in Metropolitan Detroit}

\author{
Orelaru Felix ${ }^{1}$, Gbadamosi Bolanle ${ }^{2}$, Ifabiyi Tolulope ${ }^{1}$, Jaiyesimi Ishmael ${ }^{2}$ \\ 'Oakland University William Beaumont School of Medicine, USA \\ ${ }^{2}$ Department of Hematology and Oncology, Beaumont Health System, USA
}

"Corresponding author: Orelaru Felix, Oakland University William Beaumont School of Medicine. Tel: +9172547216; Email: foorelaruajulo@oakland.edu

Citation: Felix O, Bolanle G, Tolulope I, Ishmael J (2018) Assessing Knowledge of Sickle Cell Trait/Disease Inheritance in Metropolitan Detroit. Arch Epidemiol: AEPD-123. DOI: 10.29011/2577-2252. 100023

Received Date: 11 September, 2018; Accepted Date: 16 October, 2018; Published Date: 24 October, 2018

\begin{abstract}
Sickle Cell Disease (SCD) is an autosomal recessive disease not specific to one race. This study aims to assess knowledge about the inheritance pattern of sickle cell disease among college students in the Metropolitan Detroit area. An electronic survey was administered to undergraduate students at Oakland University, and first through fourth year medical students at Oakland University William Beaumont School of Medicine (OUWB). The primary analysis compared knowledge of sickle cell disease inheritance pattern between different demographic categories. A total of 146 Oakland University (27.4\%) and OUWB (72.6\%) students responded to the survey. The average age of the respondents was $24.27 \pm 4.09$. The majority of respondents were female (61\%) and white (72.6\%). In total, three (3) respondents - 1 white, 1 Asian and 1 African American, reported knowing that they have sickle cell disease/trait. In addition, one (1) white female respondent reported having an infant carrying the sickle cell trait. Most respondents (95.9\%) knew that sickle cell disease/trait is genetically inherited, but a majority believed that it is associated only with African-Americans (67.8\%). Respondents who were college graduates were more likely to correctly identify SCD inheritance patterns $(98 \%$ compared to $85 \%$ of undergraduates; $\mathrm{p}=0.002)$ and less likely to correctly answer the question "Who gets the disease?" ( $24 \%$ compared to $63 \%$; $p<0.001)$. Most respondents $(75 \%)$ think people should know if they have sickle cell trait/disease before marriage. The result shows that most respondents believe sickle cell disease is specific to African-Americans. However, because it is equally possible for all races to inherit this disease, knowing one's status could help prevent sickle cellrelated deaths during rigorous exercises and enable individuals of reproductive age to make informed reproductive decisions in order to decrease sickle cell disease prevalence, and its associated financial and psychosocial burdens
\end{abstract}

Keywords: Community; Education; Health Care Survey; Health Education; Sickle Cell Disease; Sickle Cell Inheritance

\section{Introduction}

Sickle Cell Disease (SCD) is an autosomal recessive genetic disorder. It is a chronic condition that is characterized by severe anemia, painful crises and organ dysfunction [1]. There are several common forms of SCD: SS, the most common and severe form of the disease (inheritance of one sickle cell gene from each parent); $\mathrm{SC}$, a milder form of the disease (inheritance of one sickle cell gene and one gene for another abnormal type of hemoglobin called " $\mathrm{C}$ "); and S-beta-thalassemia (inheritance of one sickle cell gene and one gene for beta-thalassemia, another inherited hemoglobinopathy)
[2]. Unlike SCD, Sickle Cell Trait (SCT), the inheritance of a single abnormal gene, is mostly asymptomatic. However, SCT has been associated with increased risk of sudden death and renal complications during strenuous exercise, particularly when the exercise is performed at high altitude, or when the subject is dehydrated or hyperthermic. For example, military service members with SCT are at higher risk of exercise-related sudden death than those without [3].

The United States government recommended newborn screening for sickle cell diseases in 1987 but it became fully implemented in all 50 states in the United States in 2006 [4]. Moreover, the National Collegiate Athletic Association has mandated universal SCT screening for all division-one student- 


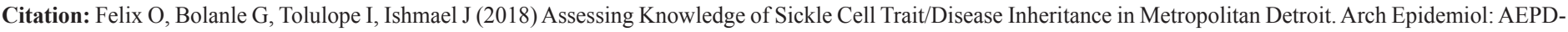
123. DOI: $10.29011 / 2577-2252.100023$

athletes to prevent exercise-related sudden death especially among athletes with unknown SCT status [5].

The CDC states that SCD affects approximately 100,000 Americans, [6] but there are about 3 million sickle cell trait carriers in the United States [3]. Though most common among African-Americans, people of other ethnic groups such as those of Arab, Indian, Hispanic, and Mediterranean descents, also carry the trait [7]. Historically, few cases of sickle cell anemia have been documented in the literature among Caucasians [8-11]. According to the 2014 Michigan state sickle cell demographics report, screening detects and diagnoses SCD in 1 of every 1907 newborns screened. In 2011, this resulted in diagnosis of 61 newborns with sickle cell disease and an additional 2,817 newborns were identified as having sickle cell trait [12]. SCD cases born in Michigan between 1988 and $2011(n=1689)$, included 3\% white and 95\% black newborns. Also, between 1987 and 2010, it was reported that SCD was more common in Detroit and Ann Arbor, combined $(73.6 \%$, sample size $=2,584)$ compared to other areas [12].

Siddiquis, et al. conducted a study in a New York City community to assess sickle cell disease knowledge [13]. $76 \%$ of African-Americans surveyed correctly defined sickle cell diseases as an inherited disorder compared to $27 \%$ of Dominicans. Also, respondents were better informed if they or family members were affected by sickle cell disease conditions. Furthermore, this assessment showed that many individuals of reproductive age affected by SCD lacked basic relevant information on disease inheritance. This data clearly indicates that in order to prevent sickle cell trait propagation in our communities, increased awareness targeted towards young adults of all races in the US is necessary to enable them make informed reproductive decisions.

This research study is novel because currently, there is no data or published articles that measure the knowledge of residents in the metropolitan Detroit area about the inheritance of sickle cell trait/disease. This study aims to assess the knowledge of college students in metropolitan Detroit area, defined as the US Census Bureau Detroit-Warren-Dearborn, Michigan area [14] in terms of economic status, race and educational level, about the inheritance of sickle cell trait/disease and awareness that sickle cell disease is not limited to any one race.

\section{Methods}

The Oakland University Institutional Review Board (IRB) approved this study. Electronic surveys were administered using Qualtrics survey software to randomly selected respondents at the Oakland University (OU) campus and Oakland University William Beaumont School (OUWB) of Medicine (Figure 1). The sickle cell disease/trait knowledge questions were adapted from questionnaires used in studies conducted by Boyd, et al. [15] and
Long, et al. [16]. The survey questionnaire used by Boyd, et al. was designed and validated by Fleming Communications, an independent marketing research corporation. The survey questions employed by Long, et al. were previously utilized and validated by the Research Center of Excellence in Minority Health Disparities (RCEMHD) at the Graduate School of Public Health, University of Pittsburgh, for Healthy Black Family Projects.

\section{Demographics: Choose the option that best applies to you}

1) What is your age?

2) What is your Gender?
a) Male
b) Female

3) Ethnicity? (Select all that apply)

a) American Indian

b) Arab

c) Asian

d) Black/African-American

e) Hispanic

f) White

g) Other

4) What is your current household size?
a) One
b) Two
c) Three
d) Four
e) Five
f) $\mathrm{Six}$

5) What is your current household income in US dollars?

a) Under $\$ 12,000$

b) $\$ 12,001-\$ 15,300$

c) $15,301-\$ 18,800$

d) $\$ 18,801-\$ 24,200$

e) $\$ 24,201-\$ 28,600$

f) More than $\$ 28,600$

6) What is the highest level of education you have completed?

a) Some college 
Citation: Felix O, Bolanle G, Tolulope I, Ishmael J (2018) Assessing Knowledge of Sickle Cell Trait/Disease Inheritance in Metropolitan Detroit. Arch Epidemiol: AEPD123. DOI: 10.29011/2577-2252. 100023
b) Bachelor's degree
c) Graduate Student
d) Other (Please specify)

7) In what country were you born? (please specify)

8) What is your partner/spouse's ethnicity? (Select all that apply)

a) American Indian
b) Arab
c) Asian

d) Black/African-American

e) Hispanic

f) White

g) Other

\section{Sickle cell diseases questions}

9) Have you ever heard of sickle cell diseases?
a) Yes
b) $\mathrm{No}$

c) Don't know

10) Do you have sickle cell trait/disease?

a) Yes.

If yes, when did you first find out?

i) New Born screening

ii) Routine doctor visit

iii) Other (please specify)

b) No

c) I have not been screened

11) Do you know someone with sickle cell diseases?
a) Yes
b) $\mathrm{No}$

c) Don't know

12) Do you know if your partner/spouse has sickle cell trait/ disease?
a) Yes
b) $\mathrm{No}$

c) Don't know

d) Not applicable
13) Do you have any child/children with sickle cell trait/disease?

$$
\text { a) Yes }
$$

If yes, how did you find out?

a) New Born screening

b) Routine doctor visit

c) Other (please specify)

b) No

c) Don't have kids

d) Don't know

14) How do you get sickle cell diseases?

a) Infection

b) Blood transfusion

c) Vaccination

d) You are born with it

e) Others (please specify)

15) Who gets sickle cell disease?

a) Black/African-American

b) Arabs

c) All races are equally likely

d) Hispanics only

e) Whites

16) People should know if they have sickle cell trait/diseases before marriage

a) Strongly agree

b) Agree

c) Somewhat

d) Disagree

e) Strongly disagree

Figure 1: Questionnaire on Sickle cell diseases/ trait awareness administered to participants in the metropolitan Detroit area.

Inclusion criteria included students between the age of 18 and 55 years old who were enrolled at OU, as well as first through fourth year medical students at OUWB. The Oakland University Office of Institution Research and Assessment randomly generated the student email list used for the study. This sample population was selected because it characterizes a diverse population of students with varying ethnicity, economic status and educational level. 


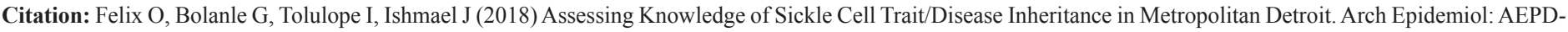
123. DOI: $10.29011 / 2577-2252.100023$

Participants were recruited and data was collected between July and September 2016. Email reminder was sent twice to increase response rate. Data analysis was completed by October 2016. An information sheet outlining the study and rights of participants was attached to all questionnaires. Waiver of consent documentation was granted by the IRB and participants were not required to sign a consent form.

The primary analysis compared knowledge of sickle cell disease inheritance between gender, education and age groups. Each of the knowledge questions was categorized as yes/no. The responses to the marriage question were coded as 1=Strongly Agree, 2=Agree, 3=Somewhat Agree, 4=Neither agree nor disagree, 5=Somewhat Disagree, $6=$ Disagree, $7=$ Strongly Disagree. Categorical variables were compared using Chi-square tests and/ or Fishers Exact test. Continuous variables were analyzed with a two-sample t-test. Descriptive statistics such as means, standard deviations, and 95\% confidence intervals were also applied.
Statistical analysis was performed using SAS/STAT Software, version 9.3 of the SAS System (Cary, NC, USA).

\section{Results}

A total of 146 people responded to the survey. The response rate was 24\%. Oakland University undergraduate students made up $27.4 \%$ of respondents, and Oakland University William Beaumont School of Medicine (OUWB) students were $72.6 \%$ of respondents. (Tables 1,2 ) report the responses to demographic and sickle cell disease questions. The majority of survey respondents from the OUWB School of Medicine were first year (38.1\%) and second year $(37.1 \%)$ medical students. The average age of respondents was $24.27 \pm 4.09(\mathrm{~N}=142$ answered this question) and the majority were college graduates $(81.5 \%)$. There were $27.8 \%$ of respondents reportinghousehold income $<\$ 10,000$ and $17.4 \%$ reporting income $\geq$ $\$ 150,000$. The majority were female (61\%) and white(72.6\%). There was $21.4 \%$ of the sample population that identified as immigrants and most respondents did not have a partner/spouse $(60.3 \%)$.

\begin{tabular}{|c|c|c|}
\hline & Response & $(\mathrm{N}=146)$ \\
\hline \multirow{3}{*}{ What is your age? } & Mean (SD) & $24.27(4.09)$ \\
\hline & Min-Max & $18.00-49.00$ \\
\hline & No response & $4(2.7 \%)$ \\
\hline \multirow{3}{*}{ What is your sex? } & Male & $56(38.4 \%)$ \\
\hline & Female & $89(61.0 \%)$ \\
\hline & Other & $1(0.7 \%)$ \\
\hline \multirow{5}{*}{ What is your race? } & White & $106(72.6 \%)$ \\
\hline & Black & $10(6.8 \%)$ \\
\hline & Asian & $21(14.4 \%)$ \\
\hline & Mixed & $4(2.7 \%)$ \\
\hline & No response & $5(3.4 \%)$ \\
\hline \multirow{6}{*}{ Highest level of school you have completed? } & High school graduate & $4(2.7 \%)$ \\
\hline & Some college but no degree & $23(15.8 \%)$ \\
\hline & Associate degree in college & $4(2.7 \%)$ \\
\hline & Bachelor's degree in college & $100(68.5 \%)$ \\
\hline & Master's degree & $14(9.6 \%)$ \\
\hline & Professional degree (JD, MD) & $1(0.7 \%)$ \\
\hline \multirow{2}{*}{ College Graduate? } & Yes & $119(81.5 \%)$ \\
\hline & No & $27(18.5 \%)$ \\
\hline
\end{tabular}


Citation: Felix O, Bolanle G, Tolulope I, Ishmael J (2018) Assessing Knowledge of Sickle Cell Trait/Disease Inheritance in Metropolitan Detroit. Arch Epidemiol: AEPD123. DOI: 10.29011/2577-2252. 100023

\begin{tabular}{|c|c|c|}
\hline \multirow{2}{*}{$\begin{array}{l}\text { Are you currently enrolled at OUWB school } \\
\text { of medicine? }\end{array}$} & Yes & $106(72.6 \%)$ \\
\hline & No & $40(27.4 \%)$ \\
\hline \multirow{4}{*}{ What year are you in? } & M1 & $40(38.1 \%)$ \\
\hline & M2 & $39(37.1 \%)$ \\
\hline & M3 & $14(13.3 \%)$ \\
\hline & M4 & $12(11.4 \%)$ \\
\hline \multirow{3}{*}{ Immigrated to the USA? } & No & $110(75.3 \%)$ \\
\hline & Yes & $30(20.6 \%)$ \\
\hline & No response & $6(4.1 \%)$ \\
\hline \multirow{7}{*}{ What is your partner/spouse's race? } & White & $45(30.8 \%)$ \\
\hline & Black & $3(2.1 \%)$ \\
\hline & American Indian & $1(0.7 \%)$ \\
\hline & Asian & $5(3.4 \%)$ \\
\hline & Mixed & $2(1.4 \%)$ \\
\hline & No Partner & $88(60.3 \%)$ \\
\hline & No response & $2(1.4 \%)$ \\
\hline
\end{tabular}

Table 1: Responses to Demographic questions.

\begin{tabular}{|c|c|c|}
\hline Question & Response & $(\mathrm{N}=146)$ \\
\hline \multirow{2}{*}{ Have you ever heard of sickle cell diseases? } & Yes & $141(96.6 \%)$ \\
\hline & No & $5(3.4 \%)$ \\
\hline \multirow{3}{*}{ Do you have sickle cell trait/disease? } & Yes & $3(2.1 \%)$ \\
\hline & No & $94(64.4 \%)$ \\
\hline & I have not been screened & $49(33.6 \%)$ \\
\hline \multirow{3}{*}{ If yes, When did you first find out? } & Routine Doctor's visit & $1(33.3 \%)$ \\
\hline & Other & $2(66.7 \%)$ \\
\hline & High school biology & $1(100.0 \%)$ \\
\hline \multirow{4}{*}{$\begin{array}{l}\text { Do you know someone with sickle cell } \\
\text { diseases? }\end{array}$} & Yes & $22(15.2 \%)$ \\
\hline & No & $105(72.4 \%)$ \\
\hline & Don’t know & $18(12.4 \%)$ \\
\hline & No response & $1(0.68 \%)$ \\
\hline
\end{tabular}


Citation: Felix O, Bolanle G, Tolulope I, Ishmael J (2018) Assessing Knowledge of Sickle Cell Trait/Disease Inheritance in Metropolitan Detroit. Arch Epidemiol: AEPD123. DOI: $10.29011 / 2577-2252.100023$

\begin{tabular}{|c|c|c|}
\hline \multirow{4}{*}{$\begin{array}{c}\text { Do you know if your partner/spouse has sickle } \\
\text { cell trait/disease? }\end{array}$} & Yes & $5(3.4 \%)$ \\
\hline & No & $38(26.0 \%)$ \\
\hline & Don't know & $25(17.1 \%)$ \\
\hline & Not Applicable & $78(53.4 \%)$ \\
\hline \multirow{4}{*}{$\begin{array}{l}\text { Do you have any child/children with sickle } \\
\text { cell trait/disease? }\end{array}$} & Yes & $1(0.7 \%)$ \\
\hline & No & $35(24.0 \%)$ \\
\hline & Don't have kids & $107(73.3 \%)$ \\
\hline & Don’t know & $3(2.1 \%)$ \\
\hline \multirow{5}{*}{ How do you get sickle cell diseases? } & Infection & $2(1.4 \%)$ \\
\hline & Blood Transfusion & $1(0.7 \%)$ \\
\hline & You are born with it & $139(95.9 \%)$ \\
\hline & Other & $3(2.1 \%)$ \\
\hline & No response & $1(0.68 \%)$ \\
\hline \multirow{3}{*}{$\begin{array}{l}\text { Responses to: How do you get sickle cell } \\
\text { diseases? If other, specify... }\end{array}$} & No clue & $1(33.3 \%)$ \\
\hline & Not sure & $1(33.3 \%)$ \\
\hline & No response & $1(33.3 \%)$ \\
\hline \multirow{3}{*}{ Who gets sickle cell disease? } & All races are equally likely & $46(31.5 \%)$ \\
\hline & Arabs & $1(0.7 \%)$ \\
\hline & Black/African-American & $99(67.8 \%)$ \\
\hline \multirow{7}{*}{$\begin{array}{c}\text { People should know if they have sickle cell } \\
\text { trait/diseases before marriage }\end{array}$} & Strongly agree & $30(20.5 \%)$ \\
\hline & Agree & $45(30.8 \%)$ \\
\hline & Somewhat agree & $35(24.0 \%)$ \\
\hline & Neither agree nor disagree & $25(17.1 \%)$ \\
\hline & Somewhat disagree & $5(3.4 \%)$ \\
\hline & Disagree & $6(4.1 \%)$ \\
\hline & Strongly disagree & $0(0 \%)$ \\
\hline
\end{tabular}

Table 2: Responses to sickle cell disease questions.

In total, three (3) respondents: one (1) white, one (1) Asian and one (1) African-American, reported knowing that they have sickle cell disease/trait. Of the three, only one respondent was an immigrant. Diagnosis of sickle cell disease/trait was made during a routine physician visit for one respondent, during a high school biology class for the second respondent, and the third respondent did not answer the question. In our sample, seven (7) couples reported at least one member with known sickle cell trait/disease (Table 3); in two cases the status of the partner was unknown. In addition, one (1) white female respondent reported having an infant carrying the sickle cell trait.

\begin{tabular}{|c|c|c|c|c|}
\hline $\begin{array}{c}\text { Do you have sickle cell } \\
\text { trait/disease? }\end{array}$ & $\begin{array}{c}\text { Do you know if your partner/ } \\
\text { spouse has sickle cell trait/disease? }\end{array}$ & Race & Partner Race & $\begin{array}{c}\text { Do you have any child/children with } \\
\text { sickle cell trait/disease? }\end{array}$ \\
\hline Yes & Yes & White & White & Don't have kids \\
\hline
\end{tabular}


Citation: Felix O, Bolanle G, Tolulope I, Ishmael J (2018) Assessing Knowledge of Sickle Cell Trait/Disease Inheritance in Metropolitan Detroit. Arch Epidemiol: AEPD123. DOI: $10.29011 / 2577-2252.100023$

\begin{tabular}{|l|c|c|c|c|}
\hline No & Yes & White & White & Don't have kids \\
\hline No & Yes & Missing & Missing & No \\
\hline No & Yes & White & White & Don't have kids \\
\hline Yes & Not Applicable & Asian & No Partner & No \\
\hline No & Yes & Missing & White & No \\
\hline Yes & No & Black & Mixed & Ylack/African \\
\hline No & Don't Know & White & American \\
\hline
\end{tabular}

Table 3: Race and status of children in respondents with SCD/SCT or a partner with SCD/SCT.

Most respondents (95.9\%) knew that sickle cell disease/trait is genetically inherited, but a majority believed that it is a disease associated only with African-Americans (67.8\%). Respondents who were college graduates (Table 4) were more likely to correctly identify SCD inheritance patterns ( $98 \%$ compared to $85 \%$ of the undergraduates; $\mathrm{p}=0.002$ ); however, they were less likely to correctly answer the question "Who gets the disease?" ( $24 \%$ compared to $63 \%$; $<0.001) .78 .3 \%$ of medical students believed that sickle cell disease is a disease specific to the African-American population, despite given the option of 'All races are equally likely' (Table 5). The average age of respondents that correctly answered the question 'How do you get sickle cell disease?' and 'Who gets sickle cell disease?' was $24.36 \pm 4.02(\mathrm{p}<0.001)$ and $22.76 \pm 3.20(\mathrm{p}<0.001)$ respectively (Table 6$)$. More male participants $(100 \%)$ correctly answered the question "How do you get sickle cell disease" compared to females (93.3\%). Also $76.8 \%$ of the male respondents believed all races are equally likely to get SCD compared to $62.9 \%$ of females (Table 7). $3.4 \%$ of the sample population reported knowing a spouse/partner has sickle cell disease/trait. Lastly, most respondents (75\%) agreed people should know if they have sickle cell trait/disease before marriage, with an average response of 2.64 \pm 1.3 , which falls between Agree and Somewhat Agree.

\begin{tabular}{|c|c|c|c|c|}
\hline Variable & Response & Not College Grad (N=27) & College Grad (N=119) & p-value \\
\hline \multirow{2}{*}{$\begin{array}{c}\text { Correctly answer question } \\
\text { about how to get sickle cell } \\
\text { disease }\end{array}$} & No & $4(15 \%)$ & $2(1.7 \%)$ \\
\cline { 2 - 5 } & Yes & $23(85 \%)$ & $116(97.5 \%)$ & $<.002$ \\
\hline \multirow{2}{*}{\begin{tabular}{c} 
Who gets sickle cell disease \\
\cline { 2 - 5 }
\end{tabular}} & Black/African American & 0 & $1(0.84 \%)$ & $90(76 \%)$ \\
\cline { 2 - 5 } & All races are equally likely & $17(37 \%)$ & $29(24 \%)$ \\
\hline
\end{tabular}

Table 4: Relationship of education to knowledge of sickle cell diseases.

\begin{tabular}{|c|c|c|c|}
\hline Variable & Response & Medical Students $(\mathrm{N}=106)$ & $\begin{array}{c}\text { Non-Medical Students } \\
(\mathrm{N}=40)\end{array}$ \\
\hline \multirow{3}{*}{$\begin{array}{l}\text { Correctly answer question about how to get } \\
\text { sickle cell disease }\end{array}$} & No & $1(0.94 \%)$ & $4(10 \%)$ \\
\hline & Yes & $105(99.1 \%)$ & $35(87.5 \%)$ \\
\hline & No response & $0(0 \%)$ & $1(2.5 \%)$ \\
\hline \multirow{3}{*}{ Who gets sickle cell disease } & Black/African American & $83(78.3 \%)$ & $16(40 \%)$ \\
\hline & All races are equally likely & $23(21.7 \%)$ & $23(57.5 \%)$ \\
\hline & No response & $0(0 \%)$ & $1(2.5 \%)$ \\
\hline
\end{tabular}

Table 5: Medical students vs. Non-Medical Students knowledge of sickle cell disease. 
Citation: Felix O, Bolanle G, Tolulope I, Ishmael J (2018) Assessing Knowledge of Sickle Cell Trait/Disease Inheritance in Metropolitan Detroit. Arch Epidemiol: AEPD123. DOI: $10.29011 / 2577-2252.100023$

\begin{tabular}{|c|c|c|c|}
\hline & $\begin{array}{c}\text { Number and Age of respondents } \\
\text { with incorrect answer }\end{array}$ & $\begin{array}{c}\text { Number and Age of respondents with } \\
\text { correct answer }\end{array}$ & p-value \\
\hline Knowledge of how you get sickle cell disease & $(\mathrm{N}=6) 20.50 \pm 1.05$ & $(\mathrm{~N}=135) 24.36 \pm 4.02$ & $<.001$ \\
\hline Knowledge of who gets sickle cell diseases & $(\mathrm{N}=97) 24.97 \pm 4.28$ & $(\mathrm{~N}=45) 22.76 \pm 3.20$ \\
\hline
\end{tabular}

Table 6: Relationship of age to knowledge questions.

\begin{tabular}{|c|c|c|c|c|}
\hline Variable & Response & Male $(\mathrm{N}=56)$ & Female $(\mathrm{N}=89)$ & Other $(\mathrm{N}=1)$ \\
\hline \multirow{3}{*}{$\begin{array}{l}\text { Correctly answered question about how } \\
\text { to get sickle cell disease }\end{array}$} & No & $0(0 \%)$ & $5(5.6 \%)$ & $1(100 \%)$ \\
\hline & Yes & $56(100 \%)$ & $83(93.3 \%)$ & $0(0 \%)$ \\
\hline & No response & $0(0 \%)$ & $1(1.1 \%)$ & $0(0 \%)$ \\
\hline \multirow{2}{*}{ Who gets sickle cell disease } & Black/African American & $13(23.2 \%)$ & $32(36 \%)$ & $1(100 \%)$ \\
\hline & All races are equally likely & $43(76.8 \%)$ & $56(62.9 \%)$ & $0(0 \%)$ \\
\hline
\end{tabular}

Table 7: Relationship of gender to knowledge of sickle cell diseases.

\section{Discussion}

Three (3) respondents out of 146 in our sample had sickle cell trait/disease. One respondent was diagnosed in a doctor's office, underscoring the opportunity for primary care physicians to provide timely information about sickle cell disease. Grant et al. suggested that care providers should repeat information about SCD to their patients at various stages of life so that they will have the knowledge at times when it is most useful to them [17]. Another respondent found out about their carrier status in a high school biology class. Therefore, it is possible that implementation of pre-school screening, though not currently utilized in the U.S., could enable more people know about their sickle cell carrier status. Olarewaju, et al. showed that most Nigerian high school students know about their status through pre-school screening [18]. In addition, $33.6 \%$ of the respondents are unaware of their SCD status. Treadwell, et al. showed in their studies that only $16 \%$ of individuals of childbearing age know their SCT status [19]. Creary, et al. explains that lack of knowledge of SCD/SCT may due to low organized SCT testing beyond the newborn screening offered statewide [20]. Also Moseley, et al. showed that 20\% of parents of children with SCT do not receive any form of counseling [21], although the CDC SCT Toolkit recommends that such individuals obtain resources about SCT testing from their physician or a local SCD not-for-profit organization (Centers for Disease Control and Prevention: Sickle Cell Trait Toolkit) [22].

Although $96.6 \%$ of the medical students surveyed were aware of sickle cell disease, similar to the $81.8 \%$ reported by Animasahun and Akitoye from a Nigerian medical institution [23], most of our medical students believe SCD is an African-American disease. An explanation for this discordance among U.S medical students could not be found upon literature review but we believe it could be because of a misinterpretation of the increased SCD prevalence among African-Americans combined with the knowledge of the genetic likelihood of anyone who carries the disease trait passing it on to the next generation. Hence renewed effort should be placed on medical education that the genetic basis of SCD means that it is equally possible for all races are to get sickle cell disease. There are a number of both historical and current reports of sickle cell anemia in non-Hispanic white American families [8,10,11], as well as other ethnic groups such as Arabic, Indian, Hispanic and people of Mediterranean descent [1,9,24].

Only $15.2 \%$ of respondents knew someone with sickle cell disease. This is not surprising because the sample population is predominantly white, and underscores that SCD is rare amongst non-Hispanic white ethnicity. However, the possibility of inheritance in the non-white population is evidenced by 1 of 3 respondents in this study who had the sickle cell trait, and identified as white. Furthermore, this same respondent has a partner whose ethnicity is also white, but has not been screened for possible SCT, thus leaving a potential for children with SCD. The majority of respondents believe that people should know their sickle cell status before marriage to allow them make informed reproductive decisions and seek genetic counseling. Although reproductive decisions are certainly multifactorial, knowledge of the possibility of inherited disease would be one important factor for prospective parents to consider. Routine testing of asymptomatic individuals upon request is in line with CDC recommendations as reported by Creary, et al. [2]. According to this report: 1) potential parents should be offered screening (if they are unaware of their sickle cell status) and preconception counseling. 2) Both parents, as they plan the pregnancy, should receive genetic counseling to determine their chances of having a child with sickle cell disease. 3) Also, it is equally important that those who carry the sickle cell trait become 


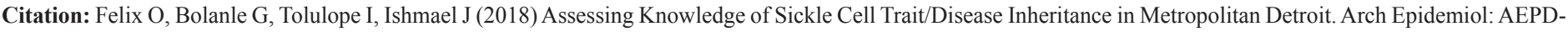
123. DOI: $10.29011 / 2577-2252.100023$

knowledgeable of their carrier status and educated on how they can potentially pass the trait or disease on to their offspring.

One explanation for the genetic inheritance of sickle cell traits is that it provides resistance to malaria, thus its high prevalence in tropical region and in African-American population [24]. However, Martinez, et al. have reported that the incidence of hemoglobinopathies such as thalassaemia and sickle cell diseases, once rare diseases in Europe, are significantly increasing in many European countries due to migration [1]. There were 30 respondents in this survey that immigrated to the US: 1 had sickle cell trait, 15 do not carry the trait, and 14 have not been screened. If individuals whose status is unknown but who may be carriers of SCT have children with other similarly at-risk individuals, a growing trend of sickle cell disease could be also observed in the US.

Inadequate phrasings of some of the questionnaire questions were limitations to this study. For example, the low response rate to the knowledge question, "Do you know if your partner/spouse has sickle cell trait/disease?" could be because the question was not properly worded. A 'No' response could mean that the respondent does not know their partners' status versus knowing that the partner is not carrying sickle cell disease/trait. A better understanding of these responses could help quantify the prevalence of SCD/SCT in the surveyed population. In addition, the question, "Who gets sickle cell disease," which is key to this study, has potentially different interpretations. The wording used forces a choice between the respondent's understanding of genetic inheritance and assumptions about prevalence of the disease in different populations, which may have been intentional in the original design of the survey, but also could have caused confusion in the respondents. However, we used the survey as worded for comparison to previous validated studies. In addition, the primary objective of this study was to assess knowledge of respondent about disease inheritance. Lastly, although our study population is similar to the greater Detroit Metropolitan area in terms of racial distribution and general level of education [14], the individuals studied had a higher proportion of females, and were younger than published demographics for the region. In addition, most individuals in the study population were medical students, thus reliable data was not obtained on household income and a relationship could not be determined between economic status and knowledge questions.

An additional limitation of our study is the low numbers of African American participants, and the restriction of our sample to college students. Although our sample population is predominantly white, educated and young, it is largely reflective of the greater metropolitan Detroit area which is also predominantly white (67\%), with over $89.7 \%$ having more than a high school education and 30\% having bachelor degrees or higher [25]. Our results may have varied had our sample been drawn from a population with more racial and ethnic diversity and different educational levels.

\section{Conclusion}

This study shows that college students from the schools surveyed in metropolitan Detroit have a high awareness of sickle cell disease. Older college students were more knowledgeable about the genetic inheritance pattern of sickle cell disease/trait compared to their younger colleagues, but more commonly assumed that $\mathrm{SCD}$ is restricted to the African-American population. Also, a majority of medical students believed it as an African-American disease compared to fewer college undergraduates. It is noteworthy that sickle cell diseases and its associated complications are often life threatening. Thus improving/increasing the awareness of asymptomatic and unknown carriers of available screening test could help reduce disease prevalence in the U.S, as it might assist prospective parents in making informed reproductive decisions.

\section{Disclosure of Potential Conflicts of Interest: The} authors report no conflict of interest.

Informed Consent: An information sheet outlining the study and rights of participants was attached to all questionnaires. Waiver of consent documentation was granted by the IRB and participants were not required to sign a consent form.

\section{Acknowledgement}

We would like to appreciate Dr. Jean Szura and Tracy Wundelich for their help during the IRB process, Ms. Michelle Jankowski for her help with the statistical analysis and Ms. Rose Callahan for her reviews.

\section{References}

1. Aguilar Martinez $P$, Angastiniotis M, Eleftheriou A, Gulbis B, Mañú Pereira M, et al. (2014) Haemoglobinopathies in Europe: health \& migration policy perspectives. Orphanet Journal Of Rare Diseases 9: 97.

2. Creary M, Williamson D, Kulkarni R (2007) Sickle Cell Disease: Current Activities, Public Health Implications, and Future Directions. Journal Of Women's Health 16: 575-582.

3. Key N, Derebail V (2010) Sickle-Cell Trait: Novel Clinical Significance. Hematology 418-422.

4. Benson J, Therrell B (2010) History and Current Status of Newborn Screening for Hemoglobinopathies. Semi Perinatol 34: 134-144.

5. NCAA Publications (2010) 2010-2011 NCAA Division I Manual (2010). Ncaapublications.com.

6. Data and Statistics on Sickle Cell Disease (2018). Centers for Disease Control and Prevention.

7. Hassell K (2010) Population Estimates of Sickle Cell Disease in the US. Am J Prev Med 38: S512-S521.

8. Cooke J, Mack J (1934) Sickle-cell anemia in a white american family. The Journal Of Pediatrics 5: 601-607. 
Citation: Felix O, Bolanle G, Tolulope I, Ishmael J (2018) Assessing Knowledge of Sickle Cell Trait/Disease Inheritance in Metropolitan Detroit. Arch Epidemiol: AEPD123. DOI: $10.29011 / 2577-2252.100023$

9. Cooley T (1929) Sickle cell anemia in a greek family. Am J Dis Child 38: 103-106.

10. Haden R, Evans FD (1937) Sickle cell anemia in the white race. Arch Intern Med 60: 133.

11. Peter AN, George RH (1979) Sickle Cell Anemia in Two White American Children: Essential Laboratory Criteria for Diagnosis. Pediatrics 63: $242-246$

12. SCDAA (2014) Annual Report: Sickle cell disease newborn screening surveillance.

13. Siddiqui S, Schunk K, Batista M, Adames F, Ayala P, et al. (2011). Awareness of Sickle Cell among People of Reproductive Age: Dominicans and African Americans in Northern Manhattan. J Urban Health 89: 53-58.

14. (2016) Census profile: Detroit-Warren-Dearborn, MI Metro Area. Census Reporter.

15. Boyd JH, Watkins AR, Price CL, Fleming F, DeBaun MR (2005) Inadequate community knowledge about sickle cell disease among AfricanAmerican women. J Natl Med Assoc 97: 62-67.

16. Long K, Thomas S, Grubs R, Gettig E, Krishnamurti L (2011) Attitudes and Beliefs of African-Americans Toward Genetics, Genetic Testing, and Sickle Cell Disease Education and Awareness. Journal of Genetic Counseling 20: 572-592.

17. Grant AM, Parker CS, Jordan LB, Hulihan MM, Creary MS, et al. (2011). Public health implications of sickle cell trait: a report of the CDC meeting. Am J Prev Med 41: 435-439.
18. Olakunle O, Kenneth E, Olakekan A, Adenike O (2013) Knowledge and attitude of secondary school students in Jos, Nigeria on sickle cell disease. Pan African Medical Journal 15: 127-136.

19. Treadwell MJ, Mc Clough L, Vichinsky E (2006) Using qualitative and quantitative strategies to evaluate knowledge and perceptions about sickle cell disease and sickle cell trait. J Natl Med Assoc 98: 704-710.

20. Creary S, Adan I, Stanek J, O'Brien S, Chisolm D, et al. (2017) Sickle cell trait knowledge and health literacy in caregivers who receive inperson sickle cell trait education. Mol Genet Genomic 5: 692-699.

21. Moseley KL, Nasr SZ, Schuette JL, Campbell A (2013) Who counsels parents of newborns who are carriers of sickle cell anemia or cystic fibrosis? J Genet Counsel 22: 218-225.

22. Sickle Cell Trait Toolkit (2018) Centers for Disease Control and Prevention.

23. Animasahun B, Akitoye C, Njokanma O (2010) Sickle cell anaemia: Awareness Among Health Professionals and medical students at the Lagos University Teaching Hospital, Lagos. Nig Q J Hosp Med 19: 195-199.

24. Al-Suwaid H, Darwish M, Sabra A (2015) Knowledge and misconceptions about sickle cell anemia and glucose-6-phosphate dehydrogenase deficiency among adult sickle cell anemia patients in al Qatif Area (eastern KSA). International Journal of Medicine and Public Health 5: 86-92.

25. U.S. Census Bureau (2016) American Community Survey 1-year estimates. 